\title{
A POTÊNCIA DA MEMÓRIA DAS MULHERES NA CONSTRUÇÃO DAS REPORTAGENS EM QUADRINHOS: A HISTÓRIA “OS PESADELOS DE GUANTÁNAMO"
}

\author{
THE POWER OF WOMEN'S MEMORY IN THE CONSTRUCTION OF COMIC \\ REPORTS: THE STORY “GUANTÁNAMO'S NIGHTMARES" \\ EL PODER DE LA MEMORIA DE LAS MUJERES EN LA CONSTRUCCIÓN DE \\ REPORTAJES CÓMICOS: LA HISTORIA "LAS PESADILLAS DE GUANTÁNAMO"
}

\author{
Christina Ferraz Musse ${ }^{1}$ \\ Cláudia de Albuquerque Thomé2 \\ Laura Sanábio Freesz Rezende ${ }^{3}$ \\ Talita Souza Magnolo ${ }^{4}$ \\ 10.21665/2318-3888.v8n15p127-160
}

\begin{abstract}
RESUMO
O jornalismo em quadrinhos vem sendo evidenciado nos últimos anos ao se apresentar como possível gênero híbrido que viabiliza a proteção de identidades no relato de crimes. Este artigo busca entender como foi feita a representação das mulheres na reportagem em quadrinhos "Os pesadelos de Guantánamo", disponível no site da Agência Pública de Jornalismo Investigativo. Objetiva-se compreender como os testemunhos, enquanto artifícios de memória, podem ser (re)significados através dessas histórias em quadrinhos, que possuem como fio condutor o contexto de conflitos, guerras e violência. Para tanto, vamos examinar esse material, buscando por estratégias narrativas que conseguiram expor e reconstruir as histórias das personagens, baseadas em entrevistas. Para a análise, utilizaremos a metodologia de Análise Crítica da Narrativa, de Luiz Gonzaga Motta (2013), e os referenciais teóricos de jornalismo em quadrinhos, de narrativas híbridas e de conceitos relacionados à importância da memória e do testemunho.
\end{abstract}

Palavras-chave: Jornalismo em quadrinhos. Gênero. Representação da mulher. Memória. Testemunho.

\footnotetext{
1 Professora Titular no Programa de Pós-Graduação em Comunicação da Universidade Federal de Juiz de Fora. Presidente da Rede de Pesquisa Alcar e líder do Grupo de Pesquisa (CNPq) Comunicação, Cidade e Memória. E-mail: cferrazmusse@gmail.com.

2 Professora Doutora dos cursos de Jornalismo e de Rádio, TV e Internet da Faculdade de Comunicação/UFJF, docente do Programa de Pós-Graduação em Comunicação da Universidade Federal de Juiz de Fora. Líder do grupo de pesquisa/CNPq Narrativas midiáticas e Dialogias. E-mail: cthomereis@gmail.com.

${ }^{3}$ Mestranda pelo Programa de Pós-Graduação em Comunicação da Universidade Federal de Juiz de Fora. Bolsista da Pró-Reitoria de Pós-Graduação e Pesquisa. Pesquisadora do Grupo de Pesquisa (CNPq) Narrativas Midiáticas e Dialogias. E-mail: laura.sanabio@gmail.com.

${ }^{4}$ Doutoranda e Mestre pelo Programa de Pós-Graduação em Comunicação da Universidade Federal de Juiz de Fora. Bolsista Capes, membro da Comissão de Audiovisual do PPGCOM da UFJF, membro do corpo editorial do Jornal da Alcar e pesquisadora do Grupo de Pesquisa (CNPq) Comunicação, Cidade e Memória. E-mail: talita.magnolo@yahoo.com.br.
} 


\begin{abstract}
Comic journalism, although not a new concept, has been gaining strength in recenty years by presenting itself as a possible hybrid genre that makes it possible to protect identities in the reporting of crimes. This article seeks to understand how women are represented in the "Declassified -The Secret Life of Gitmo's Women" comic, available on the website of the Agência Pública de Jornalismo Investigativo. The objective is to understand how the testimonies, as memory devices can be (re)signified through these comics trips, which have as their guiding thread the context of conflicts, wars and violence. To this end, we seek to examine this material, looking for narrative strategies that managed to expose and reconstruct the stories of the characters, based on interviews. For the analysis, we will use the Narrative Critical Analysis methodology, by Luiz Gonzaga Motta (2013), and theoretical references of Comic Journalism, hybrid narratives and concepts related to the importance of memory and testimony will be used.
\end{abstract}

Keywords: Comic Journalism. Genre. Representation of women. Memory. Testimony.

\title{
RESUMEN
}

El periodismo cómico, aunque no es un concepto nuevo, ha ido ganando fuerza en los últimos años al presentarse como un posible género híbrido que permite proteger las identidades en la denuncia de delitos. Este artículo busca comprender cómo se representa a las mujeres en el cómic "Pesadillas de Guantánamo", disponible en el sitio web de la Agencia Pública de Periodismo de Investigación. El objetivo es comprender cómo los testimonios, como dispositivos de memoria pueden (re)significarse a través de estas tiras cómicas, que tienen como hilo conductor el contexto de conflictos, guerras y violencia. Con este fin, buscamos examinar este material, buscando estrategias narrativas que lograr on exponer y reconstruir las historias de los personajes, basadas en entrevistas. Para el análisis, utilizaremos la metodología de Análisis Crítico Narrativo, de Luiz Gonzaga Motta (2013), se utilizarán referencias teóricas del periodismo cómico, narraciones híbridas y conceptos relacionados con la importancia de la memoria y el testimonio.

Palabras clave: Periodismo cómico. Género. Representación de mujeres. Memoria. Testimonio. 


\section{Introdução}

As reportagens feitas em quadrinhos que se destacaram na história do jornalismo em $\mathrm{HQ}$ são, em sua maioria, sobre conflitos, guerras e situações políticas (PAIM, 2011). Isso porque, se analisarmos eticamente e até mesmo nos termos da lei, os rostos das vítimas, principalmente aqueles menores de idade, devem ser cobertos em uma entrevista para TV e não podem ser divulgadas fotos nos impressos tradicionais. No entanto, na construção de uma narrativa jornalística, é importante dar rosto aos personagens. As reportagens em quadrinhos permitem que os personagens sejam representados sem que fiquem expostos a riscos e, na sua afirmação como gênero jornalístico, podem trazer elementos narrativos para garantir a veracidade do que está sendo contado, seguindo o efeito de real conceituado por Barthes ${ }^{5}$.

A história "Os pesadelos de Guantánamo" foi escolhida para análise pela sua importância em expor questões relacionadas ao gênero ${ }^{6}$ feminino, através de um mecanismo jornalístico, que é um potencial incentivo à realização de denúncias. Os quadrinhos vêm ganhando força nos últimos anos, fato que é corroborado pelo número de prêmios conquistados por reportagens quadrinísticas no ramo jornalístico. Isso mostra a relevância de se falar e estudar o jornalismo em quadrinhos, que surge como uma forma alternativa ao jornalismo impresso tradicional. Além disso, nossa escolha foi influenciada também pelo veículo em que a reportagem foi publicada, já que as matérias da Agência Pública são de fácil acesso - online, gratuito e irrestrito -, mostrando-se uma boa fonte de material para pesquisa.

A reportagem escolhida tem as mulheres - Laura e Melanie - como personagens principais. Entendemos que dar voz a elas é muito importante, pois são as principais vítimas dos diversos tipos de violência. Segundo uma pesquisa do Ministério da Saúde, de 2018, a cada quatro minutos uma mulher é agredida por pelo menos um homem no Brasil. Foi constatado, ainda, que, em $68 \%$ dos casos de violência, as vítimas são do sexo feminino. Esses dados mostram a urgência de debates nas mídias sobre a violência

5 Conceito de Roland Barthes (1980), também utilizado por Luiz Gonzaga Motta (2013), que diz respeito a uma simulação de presença na narrativa.

6 Entendendo o gênero como uma construção social. 
contra a mulher e justificam ainda mais a relevância de tais pautas no jornalismo, em seu compromisso social. Os números são alarmantes e ficam ainda mais impactantes quando deixam de ser apenas números nas reportagens que apresentam denúncias com personagens, em relatos mais humanizados e que podem gerar identificação.

No Brasil, a violência psicológica, bastante presente no quadrinho analisado, é disposta em Lei desde 2006, sendo caracterizada como "qualquer conduta que the cause dano emocional e diminuição da autoestima, ou que the prejudique e perturbe o pleno desenvolvimento" (SOUZA; CASSAB, 2010, p. 40). Apesar do avanço em relação ao combate desse tipo de prática, a violência psicológica ainda não é considerada, por muitos países, um problema social de saúde pública.

Este artigo tem como objetivo examinar as estratégias narrativas utilizadas na reportagem em quadrinhos, buscando compreender a construção da representação das mulheres dentro das possibilidades do jornalismo em quadrinhos, levando em conta, principalmente, o papel da memória e do testemunho na história. Para analisar a representação da mulher presente na reportagem em quadrinhos "Os pesadelos de Guantánamo", utilizaremos a metodologia de Análise Crítica da Narrativa e conceitos usados por Motta (2013), como o da construção dos personagens, enredos, contextos e estratégias argumentativas.

Dentro desse cenário de mulheres em situação de risco, buscamos compreender como se dá a construção da memória de mulheres vítimas de violência, entendendo também a importância dos testemunhos e depoimentos para a construção do material jornalístico, que foi capaz de, além de informar, denunciar a violência contra as mulheres. Será levantada a hipótese de que as mulheres são mostradas como vítimas de opressão, mesmo nos quadrinhos que falam sobre trabalho ou sobre a conjuntura internacional.

$\mathrm{Na}$ busca por compreender como os quadrinhos podem ser vistos como narrativas híbridas, serão estudados aspectos sobre as narrativas migrantes, a partir de Figueredo (2010). Conceitos como autorreferencialidade, correferencialidade, dialogia e atorização, de Piccinin e Soster (2016), também serão utilizados para auxiliar na definição do jornalismo midiatizado e suas características. Em outro momento, buscando suporte teórico sobre o jornalismo em quadrinhos, adotaremos como base as análises 
de Muanis (2013) sobre o quadrinho documental.

Chamamos atenção para o fato de a reportagem escolhida ser fruto de uma entrevista realizada por Sarah Mirk já voltada para a construção de uma reportagem em quadrinhos. Por isso, devemos considerar alguns conceitos, aspectos e percepções sobre a importância da preservação das lembranças e conservação de registros, responsáveis por reconstruir uma narrativa do passado pessoal e político da personagem. Partimos do pressuposto de que a memória é um fenômeno social - podendo ser classificada como individual ou coletiva - e a sociedade se comporta como produtora de conhecimentos e história. Propomos que a memória recente não é reconstituída somente pela entrevista, mas também através de documentos, como é o caso dessa reportagem, que são capazes de guardar resíduos do passado. Para embasar os conceitos sobre memória, trabalhamos com Halbwachs (1990) e, com relação ao estudo e compreensão sobre a testemunho e entrevistas, usamos como suporte bibliográfico, a obra de Alberti (2004).

\section{O quadrinho documental e as webcomics no jornalismo}

As narrativas que misturam texto e imagem começaram a surgir ainda no século XVIII. Na metade do século XIX, surgiram os quadrinhos, que se mostraram produtos híbridos. Nos anos 1990, a obra "Palestina", do jornalista maltês Joe Sacco, deu origem à expressão "Jornalismo em Quadrinhos" (JQ). A reportagem juntou texto jornalístico, imagens e desenhos para mostrar os conflitos na Bósnia e na Faixa de Gaza. A reportagem foi bastante difundida no mundo, inclusive no Brasil, quando foi publicada pela Folha de S. Paulo, no dia 19 de agosto de 2007, ocupando cinco páginas da edição de domingo. Em uma entrevista divulgada pelo jornal Estado de S. Paulo, Sacco conta com detalhes os conflitos que presenciou nos momentos de guerra entre Palestina e Israel e explica o porquê de ter escolhido o formato de quadrinhos para evitar a morbidez ao retratar os massacres.

Bem, não queria esfregar tudo na cara dos leitores. A coisa boa do desenho é que serve como filtro. Não sei quanto a você, mas se eu visse um filme com aquelas imagens... É de deixar doente. Mesmo fotografias, seria difícil ver um livro com fotografias de situações como aquelas. Com desenho, não se pode dizer que seja agradável, mas é possível olhar. Além disso, até onde sei, não há fotos daqueles massacres. Com o desenho, com acesso a fotografias de como 
eram as pessoas ou os campos de refugiados, você pode até certo ponto recriar isso. (COZER, 2010).

As reportagens em quadrinhos passaram a ser mais valorizadas, conquistando prêmios nacionais e internacionais, como é o caso da HQ "Meninas em Jogo", da Agência Pública, que venceu o prêmio Tim Lopes de Jornalismo Investigativo. Os quadrinhos mostram ter potencial também para reportagens no meio político. Em 30 de maio de 2018, o jornal italiano // Manifesto ${ }^{7}$ publicou uma história em quadrinhos homenageando a vereadora do PSOL do Rio de Janeiro Marielle Franco, executada no dia 14 do mesmo mês. A reportagem, que recebeu o nome de "Como Angela Davis"8, contava, em quatro páginas, a história de Marielle e a reconstituição de seu assassinato. O exemplar impresso, que foi vendido junto com o jornal nas bancas italianas, circulou em formato de tabloide. A versão digital ainda está disponível no site do //Manifesto, no valor de dois euros. Em entrevista ao jornal O Globo ${ }^{9}$, os autores dos quadrinhos, Assia Petricelli e Sergio Riccardi, contaram que encontraram nessa história o exemplo que precisavam para, depois de cinco anos querendo fazer quadrinhos, produzirem um jornal gráfico. Comovidos pela história, os autores, com suas próprias palavras, disseram: "com nossos meios, palavras e design, queríamos nos colocar a serviço dessa história". O formato em quadrinhos possibilitou a reconstituição das cenas da vida de Marielle e até mesmo a inserção da imagem da vereadora em imagens de manifestações que aconteceram depois de sua morte.

O avanço da tecnologia e das publicações online possibilitou a criação de hipertextos, que são elementos que permitem que o(a) leitor(a) tenha acesso a outros conteúdos relacionados àquele produto, sem ter que, necessariamente, seguir uma linearidade. Quando os quadrinhos possuem essas características ou são feitos exclusivamente para circulação na internet, eles são classificados como webcomics. É o caso de muitos

7 Disponível em: <https://store.ilmanifesto.it/products/per-marielle-franco>. Acesso em 07 de maio de 2020.

8 As informações sobre os quadrinhos "Como Angela Davis", publicados no jornal "// Manifesto", foram retiradas do artigo "Jornalismo em quadrinhos como gênero híbrido: a trajetória e a morte de Marielle Franco", de Laura Sanábio e Cláudia Thomé, apresentado nas $6^{\underline{a}}$ Jornadas Internacionais de Histórias em Quadrinhos. Disponível em: <http://www2.eca.usp.br/jornadas/programacao.php>. Acesso em 07 de maio de 2020.

9 Disponível em:

$<$ https://oglobo.globo.com/rio/italianos-homenageiam-marielle-franco-em-hq-como-angela-davis22571042>. Acesso em 13 de abril de 2020. 
fanzines atuais, que são feitos por amadores em páginas especializadas na web, e de reportagens em quadrinhos, como é o caso das matérias da Agência Pública de Jornalismo Investigativo, incluindo a reportagem escolhida para análise.

No caso dos quadrinhos da revista Symbolia, essa relação com o digital é ainda mais intensa. Todas as reportagens foram feitas para serem lidas em tablets, iPads e Kindles. Segundo a descrição do próprio site, em tradução livre ${ }^{10}$, a Symbolia é uma revista de jornalismo ilustrado desenvolvida para tablets, combinando reportagens profundas com ilustrações e quadrinhos. Ela tem o objetivo de fornecer uma experiência envolvente para uma nova geração, podendo ser baixada no iPad ou através de inscrição na edição em PDF.

Sobre a mistura de diversos meios comunicacionais, Figueiredo (2010) afirma que houve uma necessidade de adaptação às novas características narrativas e aos novos tempos, modificados pelo mercado e pelos interesses do público. Segundo a pesquisadora (2010, p. 62), "textos e imagens deslizam de um suporte para outro, intensificando-se o intercâmbio entre os diferentes meios, o que ocasiona mudanças de significado dos objetos que se deslocam, exigindo mudanças nos protocolos de leitura".

O jornalismo em quadrinhos surge como um possível gênero híbrido que possibilita que novas linguagens surjam dentro do jornalismo. O pesquisador Luiz Beltrão buscou, ainda na década de 1960, fazer uma separação dos gêneros jornalísticos de acordo com as funções que eles exercem em relação ao leitor, dividindo-os entre informativo, opinativo e interpretativo.

O jornalismo informativo englobaria notícias, reportagens e entrevistas (BELTRÃO, 1985), enquanto o opinativo diria respeito a artigos, críticas e editoriais e crônicas. Seguindo essa divisão, Beltrão (1985, p.123) classificou as histórias em quadrinhos no jornalismo, que ele chama de comic, como parte do gênero jornalístico "caricatura", essencialmente opinativo. Anos antes, Marques de Melo (1972) havia relacionado os

10 Texto original: "Symbolia is a tablet magazine of illustrated journalism that pairs incendiary reporting with thoughtful illustration and comics. Our goal is to provide an immersive, engaging experience for a new generation of newshounds. Download Symbolia on the iPad. You can also subscribe via our PDF Edition". Disponível em: <https://symboliamag.tumblr.com/about>. Acesso em 13 de abril de 2020. 
quadrinhos ao entretenimento, mas, nas obras posteriores, o autor reclassificou os quadrinhos como um material entre o opinativo e o informativo. Por fim, após a popularização da nomenclatura "Jornalismo em quadrinhos", que aconteceu na década de 1990, esse material, segundo Guimarães e Silva (2003), foi classificado como um gênero jornalístico especializado, com linguagem própria e hibridização dos modos de produção e de reprodução.

As narrativas híbridas, como é o caso dos quadrinhos, têm sido bastante exploradas nas biografias. Apesar de a expectativa da reportagem "Os pesadelos de Guantánamo" ser a abordagem de uma temática comum a diversas mulheres, ela conta o relato biográfico de duas moças - Laura e Melanie.

As biografias em quadrinhos costumam contar histórias dos indivíduos comuns. Essa temática do ser ordinário também entra nas discussões sobre autoficção. No caso das reportagens em quadrinhos, que contam com jornalistas conhecidos, o anonimato talvez não esteja tão presente, mas entra em jogo um outro aspecto importante: o bastidor. Assim como no jornalismo midiatizado (PICCININ; SOSTER, 2016, os quadrinhos apresentam os bastidores como narrativa paralela em que o jornalista se apresenta também como personagem. Os bastidores das entrevistas, que buscam refazer a memória das personagens, serão analisados com mais profundidade nos tópicos seguintes.

\section{A participação das mulheres nos quadrinhos e a representação de gênero}

Apesar de a produção e a aparição de mulheres no ramo dos quadrinhos se desenvolver de maneira diferente em locais diversos, pode-se afirmar que o cenário atual tem sido ampliado com as novas possibilidades criativas no trabalho feminino (VERGUEIRO, BOFF, 2016). Muitas mulheres iniciam sua carreira nos quadrinhos através dos relatos autobiográficos ou em criações humorísticas. A categoria humorística, principalmente, aparece como um campo privilegiado, em que as mulheres podem se afirmar como representantes da perspectiva de gênero, "garantindo que as vozes das mulheres também sejam ouvidas no meio, não mais como coadjuvantes, papel que sempre lhes foi 
delegado pela perspectiva masculina, mas como protagonistas de suas próprias histórias" (VERGUEIRO, BOFF, 2016, p. 80).

O aumento da participação feminina pode ser consequência de diversos fatores, entre eles, o aparecimento da internet. $\mathrm{O}$ ambiente virtual ajudou a alavancar as produções independentes, que facilitam a divulgação de materiais próprios sem a necessidade de uma produtora conhecida.

Nesse sentido, pode-se entender que a ocupação desse universo virtual pelos produtores de histórias em quadrinhos, em especial criadoras femininas, evidencia o preenchimento de uma carência por canais para divulgação de uma produção artística que se encontrava represada, tolhida mesmo, nos ambientes mais tradicionais - entenda-se, impressos - de publicação e divulgação (VERGUEIRO; BOFF; 2016, p. 82).

As personagens femininas ganham menos destaque em relação aos masculinos, tanto na TV quanto no cinema. Essa realidade não é diferente nos quadrinhos. A maioria dessas personagens recebe uma atenção secundária ou sexualizada. Apesar de a participação das mulheres nos quadrinhos não garantir, necessariamente, uma perspectiva de gênero, é importante ressaltar que a conquista desse espaço traz mudanças no modo de apresentação dessas mulheres. Para tentar promover um discurso de resistência, divulgar os trabalhos de quadrinhos e dar destaque ao protagonismo feminino, surgiram alguns projetos, como o "Mina de $\mathrm{HQ}^{\prime 11}$. O site reúne, em um selo independente, pesquisas, marcas, eventos e produções de histórias em quadrinhos feitas por mulheres, trans e pessoas não binárias.

As mulheres passaram a ganhar mais espaço não só como personagens, mas também como produtoras de conteúdo, no ramo dos quadrinhos, como é o caso da própria Agência Pública. Fundada por repórteres mulheres, em 2011, a agência surge como uma possibilidade de rompimento das relações assimétricas de gênero dentro do jornalismo, dando espaço tanto para jornalistas mulheres quanto para protagonistas mulheres em suas pautas.

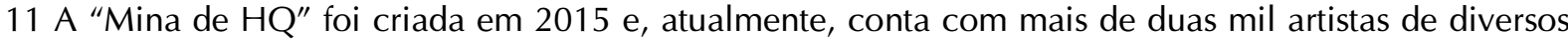
países. A maioria de suas produções envolve temas como sexualidade, igualdade de gênero, política, feminismo, autocuidado e o dia a dia da mulher. Além disso, as organizadoras, dentre elas Gabriela Borges e Ellie Irineu, oferecem palestras, workshops, cursos e projetos associados aos quadrinhos, através de uma perspectiva, de acordo com elas "feminista, antirracista e interseccional". Disponível em: <https://minadehq.com.br/>. Acesso em 11 de abril de 2020. 
A Pública é uma agência sem fins lucrativos que tem sua hospedagem na internet garantida por doações de fundações privadas e financiamento coletivo para realizar suas reportagens. A ideia tomou forma através de reportagens investigativas de interesse público $^{12}$, que já foram publicadas em mais de 700 veículos de comunicação, com a promessa de promover debates democráticos e garantir o acesso à informação. O site da Agência Pública conta com o acervo de reportagens multimídia, entrevistas realizadas com especialistas e personalidades públicas, vídeos, documentários, curtas, e projetos com levantamento de dados estatísticos, além de alguns quadros especiais, e uma aba destinada apenas para reportagens em quadrinhos, onde se destaca a HQ aqui analisada.

Os quadrinhos que abordam aspectos sobre a representação feminina ou tratam de personalidades mulheres têm se destacado nos últimos anos, tanto no ramo da literatura quanto no do jornalismo. A obra "Mulheres de 30", da quadrinista Cibele dos Santos, foi indicada para o Troféu HQMix, uma das principais premiações de quadrinhos no Brasil. Os quadrinhos "Meninas em Jogo", da Agência Pública, venceram o Prêmio Tim Lopes de Jornalismo Investigativo em 2013.

Para entendermos a representação das mulheres na reportagem "Os pesadelos de Guantánamo" e dos tipos de violência sofridos por elas, é preciso recorrer às teorias de gênero e a ideia de que a identidade feminina seria uma construção da sociedade, e não uma definição biológica. Simone de Beauvoir já defendia que:

Ninguém nasce mulher, torna-se mulher. Nenhum destino biológico, psíquico, econômico define a forma que a fêmea humana assume no seio da sociedade; é o conjunto da civilização que elabora esse produto intermediário entre o macho e o castrado que qualificam de feminino (BEAUVOIR, 1967, p. 9).

Balestero e Gomes (2015, p. 46) também defendem o parâmetro biológico não deveria servir como argumento para definir hierarquias, pois "os papéis desempenhados pelos gêneros advêm de uma construção histórica e social que determinou a cada um dos sexos os seus limites de atuação em todas as áreas". Ou seja, essa divisão não é natural e, sim, realizada através de parâmetros socioculturais

O conceito de gênero, como categoria sociológica consiste na maneira em que as diferenças entre homens e mulheres são inseridas nas mais diversas sociedades ao longo do processo histórico evolutivo, não estando relacionado

12 Disponível em:<https://apublica.org/transparencia/>. Acesso em: 19 de outubro de 2019. 
às assimetrias biológicas existentes entre macho e fêmea, qualificadas por sexo, mas sim ao universo onde as inter-relações socioculturais são determinadas por fatores como leis, regras, simbologia e patriarcalismo. (BALESTERO; GOMES, 2015, p. 46).

Para Gomes (2008), para avaliar as questões de gênero, é preciso que seu entendimento seja articulado "à classe social e raça/etnia, inserindo-se numa discussão mais ampla sobre os aspectos estruturantes na reprodução e produção da identidade social e subjetiva, das relações e das instituições sociais" (GOMES, 2008, p.239). Essa configuração influencia diretamente na noção de masculinidade, conceito importante para entender as relações de gênero. Ainda segundo o autor, a articulação entre masculinidade e violência vem sendo cada vez mais acentuada, devido a uma "associação mecânica entre o ser masculino e o ser violento".

\section{A história “Os pesadelos de Guantánamo"}

A reportagem "Os pesadelos de Guantánamo" foi originalmente publicada pela revista americana Symbolia, em fevereiro de 2014, com o título Declassified - The Secret Life of Gitmo's Women. O trabalho chegou a ser exibido durante o China Women's Film Festival 2017, um evento anual que acontece desde 2013 com o intuito de promover os direitos das mulheres e a igualdade de gênero nas áreas de artes. Em 2015, a obra, escrita por Sarah Mirk e ilustrada por Lucy Bellwood, foi traduzida para o português pela Agência Pública de Jornalismo Investigativo e publicada em sua página oficial no dia 6 de junho do mesmo ano.

A ilustradora e cartunista Lucy Bellwood ${ }^{13}$ já trabalha com séries e com relatos autobiográficos. Ela é autora do livro Baggywrinkles: a Lubber's Guide to Life at Sea, que é uma espécie de guia para sobreviver no mar. Em parceria com Sarah Mirk, Lucy ilustrou os quadrinhos Who is Woman, Anyway?, uma recriação feminista da história da Mulher Maravilha.

13 Disponível em: <https://lucybellwood.com/>. Acesso em 13 de abril de 2020. 
Sarah Mirk ${ }^{14}$ foi jornalista do jornal The Intercept e em todos os seus trabalhos buscou explorar questões sobre gênero e política. Ela foi editora durante quatro anos (20132017) do podcast "Propaganda", que abordava feminismo e cultura pop no Bitch Media ${ }^{15}$. Além disso, a autora ainda escreve, edita e desenha histórias de quadrinhos de não-ficção, como é o caso de seu projeto atual sobre o presídio de Guantánamo, chamado de Guantánamo’s Voice. Sarah, que já vinha pesquisando sobre a história da penitenciária, reuniu relatos orais de prisioneiros e de ex-funcionários em um livro com novas narrativas. A previsão de lançamento do material é setembro de 202.

Guantánamo é a prisão mais cara do mundo, conhecida por receber pessoas consideradas terroristas, durante a chamada "guerra ao terror", após os ataques de 11 de setembro de 2001 aos Estados Unidos. A prisão é localizada em uma baía no leste de Cuba e mantida pelos Estados Unidos. Atualmente, segundo reportagem da BBC Brasil (2019), "restam apenas 40 prisioneiros, todos muçulmanos e a maioria com mais de 15 anos ali, no calor sufocante dos trópicos". Guantánamo chegou a ter 700 presos, a maioria sem ter passado por julgamentos. A penitenciária era considerada uma "prisão secreta" e pouco se sabia sobre ela. Na primeira página de "Os pesadelos de Guantánamo" (Imagem 1), a autora diz que os quadrinhos mostram "algumas das poucas imagens que o mundo associa à Base Naval da Baía de Guantánamo", reforçando o sigilo e a dificuldade de se obter informações e imagens da prisão.

14 Disponível em: <https://www.mirkwork.com/about-sarah-mirk-journalist>. Acesso em 13 de abril de 2020.

15 Disponível em: <https://www.bitchmedia.org/>. Acesso em 13 de abril de 2020. 
Imagem 1 - Primeira página da reportagem "Os pesadelos de Guantánamo"

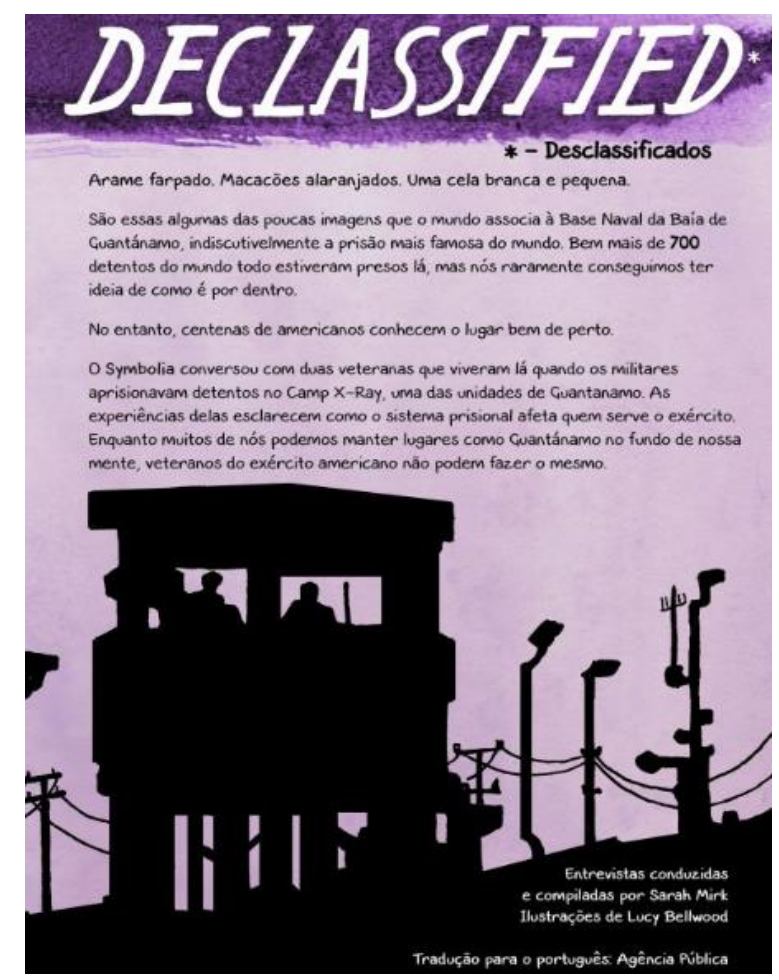

Fonte: Reprodução Agência Pública. Disponível em: https://apublica.org/2015/07/os-pesadelos-deguantanamo.

O enredo de "Os pesadelos de Guantánamo" gira em torno da violência física e simbólica sofrida por militares mulheres, que trabalham nesta prisão.

A violência simbólica representa uma forma de violência invisível que se impõe numa relação do tipo subjugação-submissão, cujo reconhecimento e a cumplicidade fazem dela uma violência silenciosa que se manifesta sutilmente nas relações sociais e resulta de uma dominação cuja inscrição é produzida num estado dóxico das coisas, em que a realidade e algumas de suas nuanças são vividas como naturais e evidentes. Por depender da cumplicidade de quem a sofre, sugere-se que o dominado conspira e confere uma traição a si mesmo (ROSA, 2007, p. 40).

Neste mesmo contexto, Mirk e Bellwood (2014, p.1) esclarecem que:

As experiências delas esclarecem como o sistema prisional afeta quem serve o exército. Enquanto muitos de nós podemos manter lugares como Guantánamo no fundo da nossa mente, veteranos do americano não podem fazer o mesmo.

Vale ressaltar que a violência simbólica não atinge da mesma forma as trabalhadoras mulheres e os trabalhadores homens da prisão de Guantánamo. Mesmo as mulheres já 
tendo conquistado direitos e alguns espaços de debate, ainda há um privilégio masculino bastante presente. Na obra "O que é violência contra a mulher?", Maria Teles e Mônica de Melo (2002) falam sobre essa diferença de tratamento, presente nos mais diversos setores da sociedade.

Constata-se que as mulheres foram perseguidas e maltratadas pelo fato de serem mulheres, diferentemente do que ocorreu com os homens, que também foram reprimidos e subordinados, mas por razões externas e não simplesmente porque eram homens. Os jovens, enquanto jovens, eram reprimidos e subordinados, mas ao se transformarem em velhos, adquiriam status e passavam a ocupar postos importantes. [...]. O mesmo não sucedia com as mulheres, que se perpetuavam como seres subordinados. (TELES; MELO, 2002, p. 30).

Pierre Bourdieu (2003, p. 7-8), define a violência simbólica como "suave, insensível, invisível a suas próprias vítimas, que se exerce essencialmente pelas vias puramente simbólicas da comunicação e do conhecimento, ou, mais precisamente, do desconhecimento, do reconhecimento ou, em última instância, do sentimento". Dessa forma, a violência simbólica legitima outras formas de poder por apresentar uma realidade dissimulada, em que até mesmo o dominado reconhece o poder exercido pelo dominante, mas sem que essa relação seja realmente problematizada.

O poder simbólico construído dentro dessa lógica (BOURDIEU, 2003) acaba criando uma construção estrutural que, ainda que não de forma consciente, corrobora e ratifica os comportamentos de submissão. Essa relação fica evidente à medida que a narrativa da reportagem vai se desenrolando. Melanie, que teve seu nome trocado por questão de segurança, sentiu-se incomodada e frustrada com a dominação masculina no seu ambiente de trabalho.

Melanie é uma veterana. Seu nome real não é Melanie. Como Laura, ela está profundamente em conflito com sua passagem pelas forças armadas. Ela orgulhosamente se juntou e serviu a Marinha quando ainda mal tinha saído da adolescência, planejando subir os degraus e construir uma carreira. Mas, enquanto servia em Guantánamo, Melanie se sentiu frustrada por seus superiores homens. Foi assediada e traída pelos colegas homens que chamava de amigos. Ela ainda tem certeza de que contar sua história levaria a retaliações e estigmatização. Esta história é uma adaptação de uma entrevista concedida anonimamente a Sarah Mirk (OS PESADELOS DE GUANTÁNAMO, 2015, p. 10).

Assim como na maioria das reportagens em quadrinhos, a história não é uma simples adaptação de uma entrevista. Por trás das matérias, existe um roteiro a ser seguido. No 
caso dos quadrinhos estudados, não há registros públicos de fotos ou de gravações das entrevistas, fruto de um acordo de anonimato entre a jornalista e as vítimas.

Um dos principais recursos utilizados para a construção do real é o uso das imagens, colocando rosto em todos os personagens. Essa construção é conceituada por Barthes (1980) como "efeito de real".

Desde os tempos antigos até as tentativas de vanguarda, a literatura se afaina na representação de alguma coisa. O quê? Direi brutalmente: o real. O real não é representável, e é porque os homens querem representá-lo por palavras e há uma história da literatura. Que o real não seja representável - mas somente demonstrável- pode ser dito de vários modos: quer o definamos, com Lacan, como o impossível, o que não pode ser atingido e escapa ao discurso, quer se verifique, em termos topológicos, que não se pode fazer coincidir uma ordem pluridimensional (o real) e uma ordem unidimensional (a linguagem). Ora, é precisamente essa a impossibilidade topológica que a literatura quer, nunca quer render-se. Que não haja paralelismo entre o real e a linguagem, com isso os homens se conformam, e é essa recusa, talvez tão velha quanto a própria linguagem, que produz, numa faina incessante, a literatura (BARTHES, 1980, p. 22-23).

Esse efeito seria um artifício que produziria no texto uma ilusão do real através das referências e dos efeitos estruturais do texto escrito. Para que esse efeito seja possível, Barthes (1980) fala da interação do real com detalhes "insignificantes", pois são esses pontos que vão aproximar o leitor do real. No caso da reportagem analisada, esse efeito se faz presente na reconstrução detalhada das cenas, nas fardas das entrevistadas e nos rostos dos personagens.

Isso não seria possível, por exemplo, se a reportagem fosse feita para TV, pois haveria a necessidade de preservar a face das vítimas. O fato de a jornalista avisar, quando os rostos ou os nomes são trocados, como no caso de Melanie, reforça seu desejo de mostrar os fatos de um jeito fiel, mas, quando não é possível, ela é leal ao leitor ao falar que a uma informação ou a face das personagens são omitidas ou trocadas.

Laura Sandow quer uma vida normal: um companheiro, um trabalho, tempo para fazer arte e caminhadas na floresta. Mas há uma grande mancha escura em seu mapa mental: as experiências trabalhando para a Marinha na baía de Guantánamo. Laura entrou para a Marinha para fugir de um relacionamento abusivo. Ela chegou à base naval antes de 11 de setembro. Quando ela saiu, Guantánamo era famosa. Como muitas outras veteranas, Laura teve dificuldade para entender seu papel na guerra ao terror e o impacto que a cultura militar teve em sua saúde mental e emocional. Esta história é uma adaptação da entrevista concedida a Sara Mirk (OS PESADELOS DE GUANTÁNAMO, 2015, p. 2). 
Cândida Gancho (1998) define o personagem como quem realiza a ação, ou seja, o ser ficcional responsável pelo desempenho do enredo. Luiz Gonzaga Motta (2013) também segue nessa linha de pensamento e ainda acrescenta a ideia de que "ação é personagem e personagem é ação". Interessa à análise pragmática identificar os motivos que levaram os personagens a serem caracterizados com seus defeitos e suas qualidades e como isto influencia na história e quais valores estão por trás dessa representação.

Partindo do princípio de que toda narrativa é argumentativa e de que não existe um texto neutro e imparcial, é hora de encontrar o propósito dessa narrativa e saber qual o papel do personagem. Busca-se, aqui, encontrar os efeitos de real, que dão veracidade, e os efeitos de sentido, responsáveis pelas emoções. No tópico a seguir, serão abordados de forma mais aprofundada os meios para a construção do testemunho e da memória dessas personagens.

\section{Os testemunhos: ferramentas da memória}

Neste artigo, é proposta a análise de uma reportagem em quadrinhos que foi elaborada através dos depoimentos, concedidos através de uma entrevista, das duas personagens principais. A seguir discorreremos sobre a importância dos testemunhos enquanto ferramentas de memória, já que a elaboração da reportagem não seria possível sem a fala das duas mulheres, cujas histórias são únicas e têm o seu valor. Worcman (2006) diz que o intenso fluxo de informações que está inundando nosso mundo globalizado, por vezes, dá a falsa impressão de que conhecemos a diversidade de nossa sociedade. As culturas se interpenetram, se tocam, mas ainda têm dificuldade em construir histórias e visões que considerem e valorizem essa diversidade.

A autora explica a diferença entre o mundo de hoje e aquele em que culturas inteiras não conseguiam enxergar além do horizonte e demoravam a entender que uma pessoa de outra cultura também deveria ser considerada como única e especial - toda pessoa tem uma história e esta história tem seu valor. Segundo a historiadora, em um mundo tão dominado pela tecnologia, todos podem e conseguem gerar e acessar informações, porém, se pudéssemos fazer nossas histórias circularem de forma menos centralizada, 
talvez teríamos de volta a memória ao nosso cotidiano, restabelecendo novamente o papel de guardiões e contadores de histórias.

MEMÓRIA, entendida no sentido original do termo, ou seja, tudo aquilo que
uma pessoa retém na mente como resultado de suas experiências. Ela é seletiva,
seja um procedimento consciente ou não. Portanto, não é um depósito de tudo
que nos acontece, mas um acervo de situações marcantes. Diante disso, então,
o que seria a história? É a narrativa que articulamos a partir dos registros de
memória. Toda história é uma articulação de passagens que ficaram marcadas.
Numa sociedade sempre há quem tenha o poder de registrá-la em jornais,
livros, arquivos, etc. Mas, na medida em que se multiplica o número das vozes,
e se ouvem mais pessoas, novos testemunhos passam a fazer parte desse grande
arquivo. Com isso, ganha a história: em diversidade, riqueza e
representatividade (WORCMAN, 2006, p. 10-11).

Nesse contexto, buscamos compreender a importância não somente da memória individual das personagens de "Os pesadelos de Guantánamo" - Laura e Melanie -, mas também da potência de seus depoimentos enquanto importantes ferramentas para a reconstrução do passado e para a construção narrativa da reportagem. É relevante apontar que os testemunhos orais trazem à tona memórias, lembranças e acontecimentos relevantes para a História que, por pouco, quase desapareceram. Todavia, eles estão sendo disponibilizados ao público, como é o caso da reportagem em quadrinhos que está sendo analisada, e possibilitando a reconstituição de uma experiência, que tem como fonte principal a memória. Mais do que isso, cabe a nós perceber que as fontes orais se incorporam às memórias vividas, antes tão marginalizadas e silenciadas, para a construção de novas identidades.

Como estamos falando de jornalismo em quadrinhos, devemos levar em consideração o testemunho das personagens, mas também da jornalista como um relato testemunhal, que possuía uma subjetividade e perspectiva próprias. A jornalista, enquanto narradora, é a responsável por fornecer os documentos que darão ainda mais veracidade aos testemunhos de terceiros. Partindo do pressuposto que os testemunhos, além de importantes para a memória, também são os responsáveis por aproximar as histórias e seus leitores. Além disso, os quadrinhos permitem a queda do mito da imparcialidade, que, apesar de nunca ter existido no jornalismo, acaba sendo uma ideia utópica que veículos de comunicação tentam passar para os leitores, através de diversas estratégias e representações, como é apresentado por Vergueiro e Oliveira (2016, p. 106) a seguir: 
É preciso levar em conta que as fotografias, as ilustrações e as tiras fazem parte de diferentes sistemas de representação e que, se é comprovado que nem mesmo fotos são registros imparciais do real (SONTAG, 2008), o diálogo empreendido por estas manifestações de expressividade não deveria almejar a construção de um bloco biográfico sólido e unívoco que traduzisse a totalidade do ser.

Em entrevista ao Observatório de Imprensa ${ }^{16}$, em 2012, Felipe Muanis reforça que “jornalismo imparcial é impossível, mas os veículos de notícia têm esse vício de esconder sua subjetividade e muitos leitores, até mesmo jornalistas, têm essa ilusão. Nos quadrinhos, o desenho e o texto explicitam que aquela é a visão do autor". Mesmo com a impossibilidade de ouvirmos as pessoas, conseguimos, durante os quadrinhos, observar e perceber diversos sentimentos. Isso se dá, principalmente, pelo uso dos desenhos, que mudam as expressões de acordo com a situação.

Os depoimentos das vítimas, seja na $H Q$, seja em outras reportagens, segundo Aline Zouvi (2016, p. 75), poderiam ser associados a uma consulta a um psicólogo ou psicanalista, pois existe, ali, um "espaço de rememoração de traumas e construção narrativa". Essa sensibilidade passada pela personagem é reforçada pela narradora, já que a reportagem "Os pesadelos de Guantánamo" contextualiza não somente um momento político e cultural, mas também o importante papel do jornalista naquele momento. Levaremos em conta que a importância do testemunho das personagens estará justamente no fato de terem vivenciado aquele momento, não importando inconsistências com datas ou nome de pessoas, o depoimento tem valor em virtude do que aquelas pessoas viveram.

Para Halbwachs (1990), as lembranças estão inseridas em um contexto social e é por isso que os indivíduos, dentro de suas relações sociais particulares, conseguem elaborar suas lembranças, tanto pessoais como também entrelaçadas com as memórias de outras pessoas. No caso de "Os pesadelos de Guantánamo", as memórias compartilhadas são extremamente pessoais, mas, de certa forma, tocam um coletivo de mulheres que sofrem abuso no mundo inteiro. Portanto, quando o autor observa que o indivíduo não tem capacidade de sustentar as suas memórias por muito tempo, porque precisaria de outros para mantê-las, é exatamente essa relação que precisa ser construída: das personagens

16 Disponível em: <https://www.mirkwork.com/about-sarah-mirk-journalist>. Acesso em 13 de abril de 2020. 
com a jornalista, das personagens com seus leitores e das personagens com as mulheres, que podem ter sofrido algum tipo de abuso.

É importante entender o jornalismo em quadrinhos e seu potencial para narrativas que trazem relatos memorialísticos sobre traumas ou denúncias de violência. Por fim, Alberti (2004, p. 77) busca relacionar os depoimentos com uma narrativa que é capaz de transmitir a realidade vivida por cada entrevistado: "ao contar suas experiências, o entrevistado transforma aquilo que foi vivenciado em linguagem, selecionando e organizando os acontecimentos de acordo com determinado sentido". A narrativa tem importante papel neste processo como constituidora de uma de muitas possíveis versões dos acontecimentos e situações passadas, se tornando assim, um importante conector entre os depoimentos e a memória das depoentes.

Para Luiz Gonzaga Motta (2013), o ato de narrar é uma experiência enraizada na existência humana, cujos primórdios estão nas mais antigas tradições de se contar histórias, de preservar uma memória, ou seja, é um modo de expressão universal onde a construção de culturas, identidades e até mesmo de uma sociedade está baseada nas narrativas de um determinado tempo e espaço. Vivemos mediante narrações e construímos nossa identidade pessoal narrando. Portanto, nossa vida é uma "teia de narrativas" na qual estamos enredados - o autor também chama isto de "mar de histórias".

Para o autor, como nos contos, reais ou imaginários, nossas narrativas nunca terminam, mas sempre nos entrelaçam, envolvendo-nos e representando-nos. A forma como organizamos nossas narrativas destaca acontecimentos, carrega significações específicas e pontua uma história pessoal e exclusiva. Narrar é dar sentido à vida, pois construímos nosso passado, nosso presente e nosso futuro.

\section{A construção narrativa através de depoimentos}

Os discursos narrativos se constroem através de estratégias argumentativas, atitudes organizadoras do texto e se utilizam de operações linguísticas para criar certas intenções e objetivos. A organização da narrativa do discurso é intuitiva, pois se realiza em 
contextos diversos, produzindo os efeitos desejados (MOTTA, 2013). As narrativas não são somente as representações da realidade, mas também formas de organizar ações em função de estratégias culturais, tornando-se dispositivos discursivos.

Nortearemos a análise a partir dos sete movimentos apresentados por Motta (2013), que auxiliarão na compreensão da construção narrativa da história "Os pesadelos de Guantánamo", bem como o entendimento de como foi feita a representação das personagens e a importância de seus depoimentos.

\subsection{Primeiro movimento: compreender a intriga como síntese heterogênea}

A primeira parte de análise propõe a identificação das partes componentes da narrativa, o que inclui os principais conflitos, os planos básicos de cada episódio, a organização do enredo, os personagens principais e os pontos de ataque.

Também chamados de pontos de virada, os pontos de ataque, segundo Motta (2013, p. 143), acontecem quando "uma ação parcial abre uma bifurcação no percurso de uma personagem ou no transcurso da intriga: virtualidade (possíveis narrativos), atualização (realização ou não) e acabamento (alternativa que predominou)". São rupturas e transgressões que dão maior tensão à narrativa.

A reportagem em quadrinhos "Os pesadelos de Guantánamo" foi escrita em 2014 e traduzida em 2015, mas a trama se passa em 2001, ano em que as duas entrevistadas passaram a trabalhar na prisão. Desde que a penitenciária foi aberta, havia uma curiosidade sobre o que se passava lá dentro. Até hoje, jornalistas, estudiosos e cidadãos comuns encontram dificuldades para conhecer as histórias de Guantánamo, que continua em atividade. Esse contexto é explicado ainda nas primeiras linhas dos quadrinhos: "Arame farpado. Macacões alaranjados. Uma cela branca e pequena. São algumas das poucas imagens que o mundo associa à Base Naval da Baía de Guantánamo, indiscutivelmente a prisão mais famosa do mundo" (OS PESADELOS DE GUANTÁNAMO, 2015. p. 1).

Na primeira página da reportagem, as personagens são apresentadas, ainda sem nome, como "duas veteranas que viveram lá quando os militares aprisionavam detentos no 
Camp-X-Ray, uma das unidades de Guantánamo" (OS PESADELOS DE GUANTÁNAMO, 2015. p. 1). As apresentações mais detalhadas começam na página 2, no caso de Laura, e, de Melanie, na página 10.

\subsection{Segundo movimento: compreender a lógica do paradigma narrativo}

Nesse movimento, analisamos a articulação interna das partes. Esse conceito busca estudar as combinações que o autor faz para atingir uma resposta emocional do interlocutor, com o objetivo de atrair e seduzir o leitor. Essa atração é feita, na maioria das vezes, através do suspense e do encadeamento dos fatos.

Nessa discussão, cabe a análise dos dêiticos, que são elementos espaço-temporais do discurso, que situam o enunciado e os sujeitos, colocando referências de momento e lugar. A reportagem começa com a apresentação dos problemas, que são a falta de informação sobre Guantánamo e as memórias sombrias que existem na prisão. "Enquanto muitos de nós podemos manter lugares como Guantánamo no fundo de nossa mente, veteranos do exército americano não podem fazer o mesmo" (OS PESADELOS DE GUANTÁNAMO, 2015. p. 1).

Os conflitos começam a aparecer ainda na apresentação de Laura, a primeira entrevistada. Em sua descrição, na página 2, é dado o contexto de "relacionamento abusivo" e "impacto que a cultura militar teve em sua saúde mental e emocional". Essa contextualização também é feita com Melanie, que teve seu nome real alterado: "Como Laura, ela está profundamente em conflito com sua passagem feita pelas forças armadas [...]. Foi assediada e traída pelos colegas homens que chamava de amigos" (OS PESADELOS DE GUANTÁNAMO, 2015. p. 10). Ao descrever o cenário geral, antes de dizer que as informações foram concedidas por entrevistas a Sarah Mirk, a autora adota estratégias narrativas que buscam envolver o leitor naquela realidade, para que ele se aproxime da trama.

A cada episódio ou mudança de narrativa, os conflitos de modificam, mas o tema é sempre o mesmo: as violências física e psicológica sofridas pelas mulheres militares que trabalharam na Baía de Guantánamo. Para auxiliar na construção dessa narrativa, a 
linguagem ganha um papel muito importante. O vocabulário, os adjetivos e verbos ajudam a contextualizar os fatos e evidenciar as emoções. Na apresentação de Laura, página 2 da reportagem, a autora começa caracterizando a entrevistada como uma pessoa que "quer uma vida normal", mas, ao mesmo tempo, fazendo um contraponto com "mancha escura em seu mapa mental", relacionada às experiências vividas em Guantánamo. Nas primeiras páginas da entrevista de Laura, ela é descrita como uma jovem que, apesar dos problemas relacionados ao casamento, mostrava-se otimista em relação ao trabalho na prisão: "A marinha abriu um treinamento. Uma chance de ir para a escola era tudo que eu precisava" (OS PESADELOS DE GUANTÁNAMO, 2015. p. 4). O serviço era tido como "legal", "todo mundo saía para se divertir". A descrição muda à medida que os acontecimentos se desenrolam. A partir daí, os problemas começam a aparecer.

A apresentação de Melanie segue o mesmo padrão. O princípio da narrativa evidencia os motivos pelos quais ela decidiu aceitar o trabalho e como o serviço em Guantánamo seria uma chance de crescimento pessoal e profissional. Tanto Melanie quanto Laura demoraram a entender o que realmente se passava na prisão, mas o encanto de Melanie durou menos que o de Laura. As festas que, para Laura, pareciam um momento de diversão, para Melanie eram "de onde vinham os problemas", como a própria entrevistada descreve na página 15 (Imagem 2). Nos quadrinhos seguintes, ela conta sobre a relação com os "amigos" - que ela deixa entre aspas - e sobre seus medos.

Imagem 2 - Melanie descrevendo como eram as festas e os bares

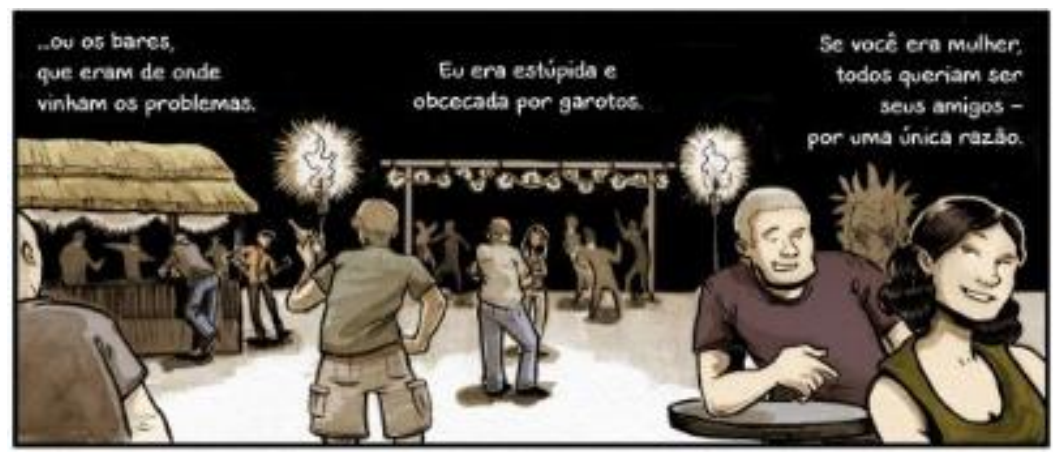

Fonte: reprodução Agência Pública. 
A frequência das palavras-chave, segundo Motta (2013), é um fator a ser analisado. Durante a narrativa, a palavra "medo" e caracterizações como "em pânico", "depressiva", "presa" e com "sentimento de impotência" aparecem frequentemente, estabelecendo conexões entre as partes dos conflitos com os pontos de ataque, que são as ações que modificam a história. Um desses pontos de ataque acontece na página 5, quando Laura diz que "então tudo mudou muito rápido. Foi muito em segredo". Na página 13, Melanie conta como foi quando começou a entender o que realmente estava acontecendo: "eu sabia que eles tinham um campo com detentos...mas não tinha me ligado até chegar lá".

A narrativa mistura verbos no pretérito e no presente do indicativo. O uso do presente é uma das marcas do jornalismo para dar a ideia de atualidade e dinamismo aos fatos. A autora optou por utilizar predominantemente o presente para falar das entrevistas e dos depoimentos. Ao detalhar os fatos acontecidos durante a apuração, a repórter utiliza verbos no pretérito, através da reconstrução das narrativas e dos flashbacks.

A frequente utilização de flashbacks, principalmente quando se trata dos depoimentos dos personagens, é uma importante ferramenta na construção dos planos básicos de cada episódio e na organização do enredo. Durante a reconstituição da história, Laura e Melanie contam sobre seu passado e tudo que viveram em Guantánamo, em uma espécie de resgate à memória. Na página 5, Laura conta como foi a mudança de rotina: "Eu tentei mergulhar. Mas quando eles começaram a trazer os detentos...nós não podíamos ficar na água". Melanie também narra sua realidade quando entrou na marinha: "Entrei na Marinha aos 20 anos. Não tinha a intenção de atuar em conflitos. Quando fui designada, não sabia nada sobre Guantánamo. Eu não estava acompanhando o noticiário".

As únicas personagens que têm nomes são Laura e Melanie. As outras pessoas desenhadas nos quadros não são identificadas. No último quadro da página 2, por exemplo, podemos ver Laura com um homem dentro de um carro. Pelo contexto citado nos quadrinhos anteriores, podemos subentender que esse homem era seu marido, mas isto não é explicitado na reportagem. O mesmo acontece na página 15, em que Melanie conta sobre o assédio que sofreu por parte dos "amigos" (Imagem 3). 
Imagem 3 - Relato de Melanie sobre os assédios sofridos por ela
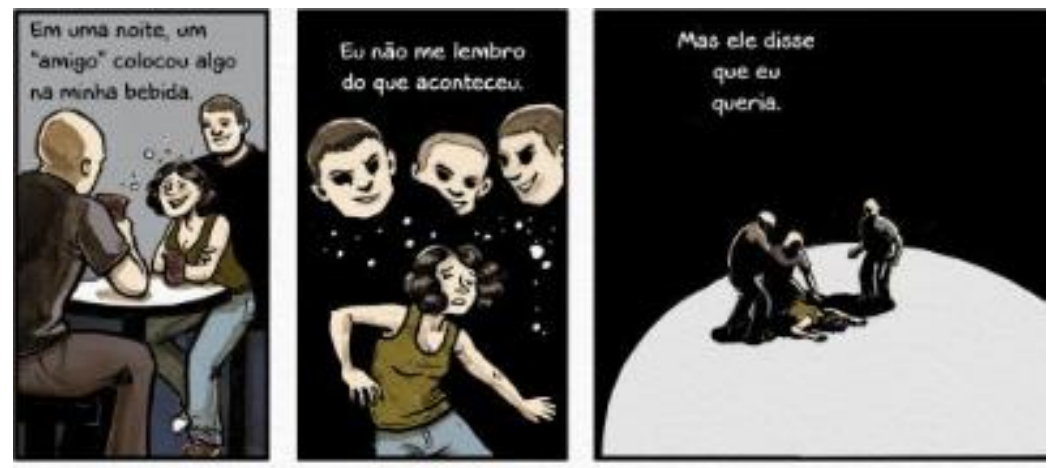

Fonte: reprodução Agência Pública.

Ela diz: "Eu não me lembro o que aconteceu. Mas ele disse que eu queria" (OS PESADELOS DE GUANTÁNAMO, 2015. p. 15). Os "amigos" foram desenhados, mas nenhum deles foi identificado no texto. Chamamos atenção para este quadro em específico, para ressaltar a importância da junção "imagem e texto" que auxiliam na produção de sentido, mas também contribuem para o entendimento emocional do leitor. Julgamos que somente o texto, neste caso, não daria o mesmo sentido.

\subsection{Terceiro movimento: deixar surgirem novos episódios}

Analisando o terceiro movimento, passamos a pensar nos novos episódios, que são "unidades temáticas narrativas intermediárias, semanticamente coesas, que relatam ações ou conjunto de ações relativamente autônomas (motivos)" (MOTTA, 2013, p. 160). Ou seja, são circunstâncias, cenários e características de personagens que podem transformar a história.

Entra aqui, também, o script, que é o acúmulo de tudo que é desenvolvido e memorizado, o repertório que adquirimos ao longo da vida e as representações dramáticas que cada ponto desencadeou em nossas vidas. Essas marcas levam o leitor a inferir algo, a interpretar. Um exemplo disso é a fala de Laura na página 6, em que ela deixa o seguinte questionamento: "Você consegue imaginar isso acontecendo agora? Enquanto nós estamos sentadas aqui?" (Imagem 4). Mesmo sem conseguirmos ouvir sua 
voz, ao analisarmos a expressão em seu rosto e o contexto que ela acabou de evidenciar, é possível perceber angústia e tristeza em sua fala.

\section{Imagem 4 - Depoimento de Laura}

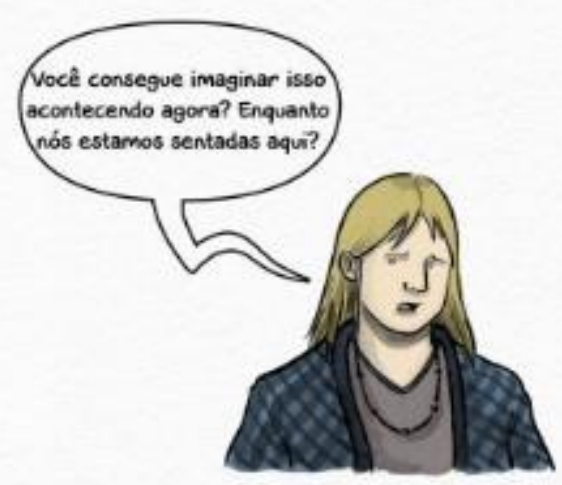

Fonte: reprodução Agência Pública.

Em uma das falas de Melanie, na página 11, também é possível fazer essa inferência. Ela diz que "teria sido muito mais fácil se eu tivesse algo pendurado entre as pernas", referindo-se ao fato de que as forças armadas têm predominância de servidores homens (Imagem 5).

Imagem 5 - depoimento de Melanie
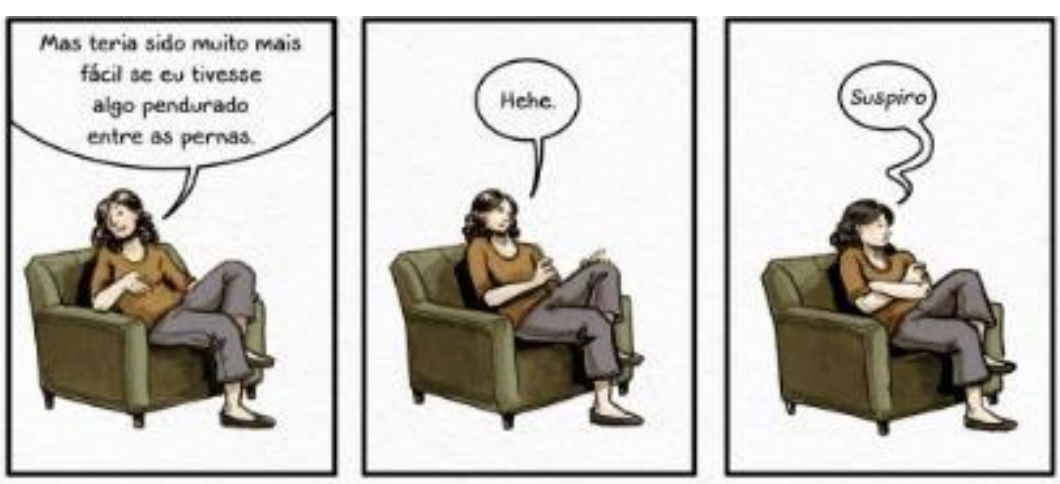

Fonte: reprodução Agência Pública. 
Ao analisarmos a frase, que é complementada com um quadrinho do lado escrito "Hehe", podemos notar o tom de deboche no que ela disse. Os desenhos e os balões nos permitem observar e perceber diversos sentimentos, ao mudarem os traços e as expressões de acordo com a situação. Cabe ao receptor observar e analisar essas mudanças.

\subsection{Quarto movimento: permitir ao conflito dramático se revelar}

O quarto movimento é caracterizado pelo enquadramento, pela perspectiva e pelo ponto de vista. Ao identificarmos os conflitos, podemos analisar as intrigas e as ações dos personagens.

O detalhamento do ambiente, as expressões faciais, os costumes e todas as outras descrições só farão sentido se o repórter souber lidar com os símbolos. Se puder atribuir significado a eles e, mais importante ainda, se tiver a sensibilidade para projetar a ressignificação feita pelo leitor (PENA, 2006, p. $55)$.

O frame é a busca do significado em relação à reconstituição das situações colocadas nas narrativas através do posicionamento do narrador. A reconstrução das narrativas das duas entrevistadas é baseada em relatos autobiográficos e, por isto, são repletos de subjetividades e emoções.

Apesar de as duas personagens, Laura e Melanie, serem as narradoras principais da narrativa, a jornalista também exerce essa função ao falar dos bastidores, apresentando as duas veteranas e explicando a escolha das fontes. Ao falar das decisões e das restrições que ela mesma se impôs, Sarah cumpre um papel muito importante na narração, que é o de explicar o contexto, como o fato de o nome de Melanie estar entre aspas, na página 10: "Melanie é uma veterana. Seu nome real não é Melanie". Ela ainda complementa, em uma tentativa de justificar essa escolha: "Ela ainda tem certeza de que contar sua história levaria a retaliações e estigmatização" (OS PESADELOS DE GUANTÁNAMO, 2015. p. 10). 


\subsection{Quinto movimento: personagem - metamorfose de pessoa à persona}

O quinto movimento define o papel dos personagens na narrativa. Este momento de estudo recebe esse nome porque, segundo o autor, "como personagens do discurso, elas representam pessoas, mas não são pessoas, são representações das pessoas" (MOTTA, 2013, p. 190). A análise busca identificar os motivos que levaram os personagens a serem caracterizados da forma como estão na narrativa, carregando seus defeitos e suas qualidades, e entender como isto pode influenciar no enredo. Essas influências se tornam ainda mais importantes nas reportagens que envolvem denúncias, como no caso estudado.

Além das duas personagens principais, somente duas outras pessoas possuem voz nos quadrinhos, um soldado, na página 13, que fala sobre o fato de os prisioneiros comerem melhor que eles, segundo ele, e um oficial, na página 17, que diz para Melanie: "Não acho que vai conseguir lidar com o treinamento avançado". O enquadramento de todos os envolvidos na história é bastante claro e bem delineado. Os oficiais da marinha e os companheiros de trabalho são assediadores, contribuindo para o ambiente violento de Guantánamo, principalmente em relação às colegas de serviço.

As vítimas que, nesse caso, são as duas entrevistadas, são bem caracterizadas. Ambas entram no Marinha com o intuito de conseguir uma boa oportunidade de trabalho e, sem saber exatamente do que se tratava aquela prisão, acabam sofrendo uma série de abusos psicológicos e até mesmo físicos. A tristeza e o medo ficam bem caracterizados tanto nas falas quanto nas expressões faciais que foram desenhadas, tanto nos flashbacks quanto no momento das entrevistas.

Laura e Melanie, como testemunhas, conquistam o "direito de fala". Segundo Motta (2013), esse direito é uma das estratégias narrativas do jornalismo, que se divide em três vozes. A primeira é o veículo de comunicação, que possui interesses comerciais e ideológicos. A segunda são a jornalista, os editores, os repórteres e ilustradores, que constroem a história e negociam com as fontes e com o jornal. No caso da reportagem analisada, a relação de poder, neste caso, fica entre a revista Symbolia, Sarah Mirk, a jornalista, e Lucy Bellwood, a ilustradora. A assinatura ou não pelo jornalista pode ser analisada como um discurso de poder. E a terceira voz é relacionada ao personagem e 
à hierarquização dos fatos. Segundo Motta (2013), todas as vozes precisam entrar em negociação para concluir a reportagem.

\subsection{Sexto movimento: as estratégias argumentativas}

Passamos para o sexto movimento, que fala sobre as estratégias argumentativas, que incluem os efeitos de real, que dão veracidade, e os efeitos de sentido, responsáveis pelas emoções. A produção de sentido foca na humanização dos fatos, na memória cultural do leitor e no seu repertório específico sobre o tipo de linguagem utilizada.

O efeito de real, de acordo com Motta (2013, p. 199), "opera uma mediação que é ao mesmo tempo linguística e temporal". Por isso, é feita uma análise dos advérbios de tempo e lugar. A linguagem tem a intenção de atingir o receptor, que por sua vez, não é um agente passivo e terá um modo diferente de resposta à leitura, dependendo das estratégias argumentativas utilizadas.

Um dos recursos para a construção desse real e dessa narrativa é o uso de imagens. Mesmo no caso de Melanie, que tem o rosto trocado, fica evidente a tentativa de mostrar os fatos de uma forma mais fiel. Se fosse em uma entrevista feita na TV, por exemplo, seu rosto seria borrado ou ocultado. O desenho permite que essa personagem tenha uma face e ainda tenha sua identidade protegida.

A referência temporal é dada somente no início e no fim da reportagem. Na página 3, podemos ver a data "outubro, 2001", dia em que as veteranas começaram seus trabalhos em Guantánamo. Na página 16, Melanie diz que conseguiu terminar os 19 meses de serviço, mostrando que todas as histórias aconteceram nesse período de tempo.

\subsection{Sétimo movimento: permitir às metanarrativas aflorarem}

Por fim, o sétimo movimento fala sobre permitir às metanarrativas aflorar. Aqui é onde são apontados os princípios éticos e morais da trama.

[...] os discursos narrativos se constroem através de estratégias comunicativas (atitudes organizadoras do discurso) e recorrem a operações e a opções (modos) linguísticos e extralinguísticos táticos para realizar certas intenções e objetivos. A organização narrativa do discurso, ainda que espontânea e intuitiva, não é 
aleatória: realiza-se em contextos pragmáticos e políticos e produz certos efeitos (consciente ou inconscientemente desejados) (MOTTA, 2013. p. 82).

A narrativa mostra que a violência vai muito além das brigas físicas. A própria dificuldade em encontrar informações sobre Guantánamo e o medo que Melanie tem em sofrer retaliações mostram como esse assédio deixa marcas. No que diz respeito à violência em si, a reportagem indica que grande parte do problema estaria na postura da própria Marinha, como fica evidente no depoimento de Melanie: "A cultura militar me mandava uma mensagem clara. Se algo acontecer com você, não conte para ninguém". Ela ainda completa, no último quadrinho da reportagem (Imagem 6), que "sempre, sempre vão escolher o homem em vez de você" (OS PESADELOS DE GUANTÁNAMO, 2015. p. 17).

Imagem 6 - Considerações de Melanie: "Sempre, sempre vão escolher o homem em vez de você"

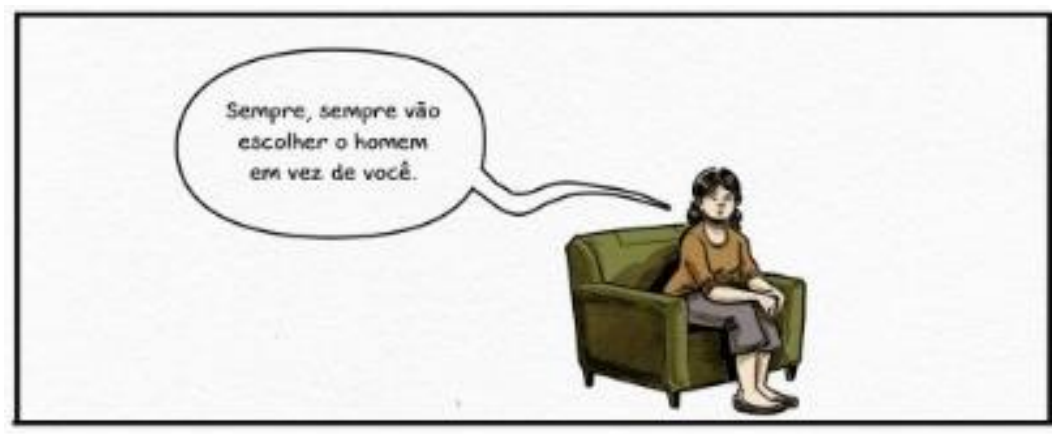

Fonte: reprodução Agência Pública.

Fica a moral da história de que a situação é mais complexa do que se possa imaginar. Em meio à violência sofrida pelos prisioneiros de Guantánamo, ainda é preciso olhar para a violência entre os agentes do estado, marcadas pela desigualdade do gênero nas instituições militares, que precisa ser considerada e ainda mais denunciada. 


\section{Considerações Finais}

No jornalismo investigativo e de cobertura de conflitos, a reportagem em quadrinhos tem se configurado como importante instrumento informativo. Um material que, antes, era indicado para o público infantil, mostra profundidade na abordagem de temas, na maioria das vezes, complexos. O jornalismo em quadrinhos vem trazendo contribuições para a sociedade, através de características que superam o simples narrar, fazendo uso da estética quadro a quadro.

Um outro aspecto interessante, sobre a reportagem em quadrinhos, é o fato de o leitor poder dar o seu próprio ritmo à leitura. Essa característica contribui para uma experiência estética mais aprofundada, especialmente em casos como o dos quadrinhos analisados, que utilizaram a troca de imagens para proteger a identidade de uma das vítimas.

Em "Os pesadelos de Guantánamo" ficou evidente que as mulheres são vítimas dos diversos tipos de violência, apesar de estarem em uma prisão com os maiores "terroristas" do mundo, o que prevaleceu na narrativa foi violência simbólica sofrida pelas trabalhadoras da prisão. Nesta reportagem, ficou evidente que o fio condutor é a memória, presente nos testemunhos das duas personagens principais. Os estudos acerca da memória provocaram uma reflexão sobre a importância dos depoimentos e da individualidade das histórias e esta reportagem não seria possível - ou pelo menos não teria o mesmo conteúdo - sem os importantes testemunhos concedidos pelas mulheres.

Neste sentido, é válido observar que a potência da memória das mulheres está justamente na possibilidade de se fazer uma denúncia contra os abusos sofridos, mas também no aprendizado que estas reportagens podem oferecer ao possibilitarem a reconstrução de eventos e episódios traumáticos. Sendo assim, podemos concluir que a importância da memória se dá de forma igual para as depoentes, quanto para a história oficial, que ganha outras percepções através das falas das pessoas, mas também para as mulheres que passaram por traumas parecidos. Além disso, é necessário deixar claro que, os quadrinhos são apenas um exemplo de vários formatos que possibilitam a produção diferenciada de uma investigação jornalística específica. No nosso caso, por exemplo, o formato possibilitou a reprodução das entrevistas e, por esse fato, de acordo 
com os estudos que apontamos sobre memória, se tornaram instrumentos de grande potência desta memória individual.

Além disso, foi possível observar a relação entre os depoimentos e a narrativa, já que no momento que contam suas histórias, as personagens criam sua própria narrativa, que por sua vez, é ressignificada pela autora da reportagem. Neste contexto, realizamos, utilizando a metodologia de Análise Crítica da Narrativa de Luiz Gonzaga Motta, um estudo sobre a construção narrativa da história "Os pesadelos de Guantánamo", buscando entender, principalmente, os artifícios narrativos e estratégias utilizadas para narrar histórias através de duas personagens - Laura e Melaine - durante suas respectivas experiências trabalhando na prisão de Guantánamo.

A análise comprovou que os testemunhos estavam inseridos em um contexto violento e de guerra e, uma vez transformados em uma narrativa jornalística, foram ressignificados e apresentados à sociedade como uma denúncia para os abusos invisíveis sofridos por mulheres que trabalharam na prisão. Ao analisar as estratégias narrativas, alguns aspectos ficaram evidentes como o fato de a autora conseguir localizar seu leitor no espaço e tempo corretos, através dos desenhos da prisão, mas também com detalhes com os quais é possível realizar uma construção mental do cenário onde esta história aconteceu. A análise detectou que esta descrição contribuiu para a reconstrução de um lugar considerado inacessível através do efeito de real (BARTHES, 1980). Além disso, foi possível observar que os principais conflitos eram elucidados em formas de termos e palavras como, por exemplo, "relacionamento abusivo", "medo", impacto na saúde mental e emocional" e "assédio".

Por vezes, a autora trouxe as diversas situações de assédio, vividas pelas personagens, de forma a envolver o leitor naquela realidade. Apesar de serem duas histórias diferentes, o mote narrativo foi o mesmo: as violências física e psicológica sofridas pelas mulheres. Isso se torna mais evidente quando a jornalista decide dar nome - mesmo não sendo o nome verdadeiro - apenas às duas personagens principais, deixando os outros sem nome, como se fossem anônimos e, de certa forma, alheios àquela situação.

Em outros momentos, a aproximação com a história acontece quando a autora coloca as personagens para dialogarem diretamente com o leitor, como é caso da frase "Você 
consegue imaginar isso acontecendo agora? Enquanto nós estamos sentadas aqui?", fala da personagem Laura. A pesquisa revelou que este artifício narrativo foi utilizado para tocar o leitor e colocá-lo para refletir sobre a situação. Além disso, observou-se parte estética dos quadrinhos contribuem para a construção e entendimento das narrativas, que no final, nos conduzem ao que Motta (2013) chama de "moral da história". Neste caso, a reportagem abordou a experiência vivida por essas duas mulheres e que estas, podiam ser quaisquer outras duas, em outras situações, evidenciando uma situação tão grave quanto a dos presos de Guantánamo. Além de informar, "Os pesadelos de Guantánamo" teve como objetivo fazer uma grave denúncia da violência sofrida pelas mulheres nas instituições militares.

\section{Referências}

AGÊNCIA PÚBLICA. Disponível em: https://apublica.org/. Acesso em: 17 de dezembro de 2019.

BARTHES, R. Aula. 14 ed. Tradução de Leyla Perrone-Moisés. São Paulo: Editora Cultrix, 1980.

BALESTERO, Gabriela; GOMES, Renata. Violência de gênero: uma análise crítica da dominação masculina. Revista CEJ, Brasília, Ano XIX, n. 66, p. 44-49, maio/ago. 2015. BEAUVOIR, Simone de. O segundo sexo. A experiência vivida (Vol. 2). 2.ed. São Paulo: Difusão Européia do Livro, 1967.

BELTRÃO, Luiz. Iniciação à Filosofia do Jornalismo. 1ed. São Paulo: Com-Arte, 1985. BBC Brasil. Por Lioman Lima. O que faz da prisão mantida pelos EUA em Guantánamo a mais cara do mundo. BBC News, 2019. Disponível em: https://www.bbc.com/portuguese/internacional-49804838. Acesso em: 13 de abril de 2020

BORGES, Gabriela. A representação da mulher e os discursos de gênero nos quadrinhos. LadysComics. Disponível em: http://ladyscomics.com.br/quanta/?portfolio=a-representacao-da-mulher-e-os-discursosde-genero-nos-quadrinhos. Acesso em: 15 de mar. de 2020.

BOURDIEU, Pierre. A dominação masculina. Tradução de Maria Helena Kühner. 3. ed. Rio de Janeiro: Bertrand Brasil, 2003.

COZER, Raquel. Histórias reais que foram esquecidas. Estadão. 2010. Disponível em: http://cultura.estadao.com.br/noticias/geral,historias-reais-que-foram-esquecidasimp-,615333. Acesso em: 29 de abr. 2020. 
FIGUEIREDO, Vera Follain. Narrativas migrantes: literatura, roteiro e cinema. Rio de Janeiro: Editora PUC-Rio, 2010.

GOMES, Romeu. A dimensão simbólica da violência de gênero: uma discussão introdutória. Athenea Digital. Número 14; 237-243, 2008. Disponível em: https://www.researchgate.net/publication/28233882_A_Dimensao_Simbolica_da_Viole ncia_de_Genero_uma_discussao_introdutoria. Acesso em: 13 de junho de 2020.

GUIMARÃES, Rafael B.; SILVA, Fabiano M. da. Jornalismo em quadrinhos: uma análise do uso da nona arte como suporte para a narrativa jornalística. Brasília: UnB, 2003.

HALBWACHS, Maurice. Memória Coletiva. Edições Vértice: São Paulo, 1990.

MARQUES DE MELO, José. Estudos de Jornalismo Comparado. São Paulo: Pioneira, 1972.

MIRK, Sarah. Os pesadelos de Guantánamo. Symbolia, 2015. Disponível em: https://apublica.org/2015/07/os-pesadelos-de-guantanamo/. Acesso em: 15 mar. 2020.

MOTTA, Luiz Gonzaga. Análise crítica da narrativa. Brasília: Editora Universidade de Brasília, 2013.

MUANIS, Felipe. O quadrinho documental e a tradução da cidade. $9^{a}$ Arte (São Paulo), (1), 45-57, 2013. Disponível em: http://www.revistas.usp.br/nonaarte/article/view/136941. Acesso em: 15 de fev. de 2020.

PAIM, Augusto. Jornalismo em Quadrinhos: os filhos de Joe Sacco, 2011. Disponível em:

$<$ http://jornalggn.com.br/blog/luisnassif/o-jornalismo-em-quadrinhos>. Acesso em: 02 de maio 2019.

PICCININ, Fabiana; SOSTER, Demétrio de Azeredo. Da anatomia do telejornal midiatizado: metamorfoses e narrativas múltiplas. Brazilian Journalism Research, São Paulo, v. 8, n. 2, p.118-134, 05 jul. 2016

ROSA, A. R. (O) Braço forte, (a) mão amiga: um estudo sobre a dominação masculina e violência simbólica em uma organização militar. Lavras: UFLA, 2007.

SOUZA, Hugo Leonardo; CASSAB, Latif. Feridas que não se curam: A violência psicológica cometida à mulher pelo companheiro. Anais do I Simpósio sobre Estudos de Gênero e Políticas Públicas, Universidade Estadual de Londrina, 2010.

TELES, Maria Cunha de Almeida; MELO, Mônica de. O que é violência contra a mulher? Coleção Primeiros Passos. São Paulo. Brasiliense, 2002.

VERGUEIRO, Waldormiro; BOFF, Edilaine de Oliveira. Histórias em quadrinhos como espaço privilegiado para afirmação de gênero: Chiquinha e o riso do feminino. In:VERGUEIRO, Waldomiro; RAMOS, Paulo; Nobu Chinen (Org). Enquadrando o real: ensaios sobre quadrinhos (auto) biográficos, históricos e jornalísticos 1 ed- São Paulo: Criativo, 2016. p. 78-97. 
WORCMAN, Karen. Introdução. In: História falada: memória, rede e mudança social / Coordenadores: Karen Worcman e Jesus Vasquez Pereira. São Paulo: SESC SP: Museu da pessoa: Imprensa Oficial do Estado de São Paulo, 2006.

ZOUVI, Aline. Auto-obsessão versus representatividade nos quadrinhos de Alison Bechdel.In: VERGUEIRO, Waldomiro; RAMOS, Paulo; Nobu Chinen (Org). Enquadrando o real: ensaios sobre quadrinhos (auto) biográficos, históricos e jornalísticos 1 ed- São Paulo: Criativo, 2016. p. 60-76.

Recebido: 08.05.2020

Aprovado: 30.06.2020 